7. Reprod. Fertil. (1965) 9, 41-46

\title{
SEASONAL VARIATION IN THE EFFECT OF PRO- GESTERONE ON OESTROUS CYCLES IN BEEF HEIFERS
}

\author{
D. R. LAMOND* \\ CSIRO Division of Animal Physiology, Pastoral Research Laboratory, \\ Armidale, N.S.W.
}

(Received 26th May 1964)

\begin{abstract}
Summary. Hereford heifers in yards were given progesterone for periods of 2 weeks, at intervals of 7 weeks over a period of 1 year. Seasonal changes in the effects of progesterone were observed. During the late winter and spring months the ovarian cycles were not suppressed by doses of progesterone that were satisfactory at other times of the year. The interval from the cessation of treatments to onset of oestrus was also shorter in the late winter/spring period.
\end{abstract}

\section{INTRODUGTION}

Administration of progesterone or synthetic progestagens to cattle suppresses oestrus and ovulation (Christian \& Casida, 1948; Zimbelman, 1961; Lamond, 1964a). Effective suppression depends on dose, frequency of injections and mode of administration, but it seems likely that satisfactory results from insemination at the first oestrus after progesterone treatments depend on factors other than those that give effective suppression. This view is based on the wide variation in fertility reported in treated groups.

One factor that may affect the use of progestagens is seasonal variation in the effect of treatments, as has been shown to occur in sheep with progesterone (Lamond, 1962, 1964b). The present paper describes an experiment designed to examine this aspect of progesterone treatment in Hereford cattle housed in yards.

\section{MATERIALS AND METHODS}

Progesterone was dissolved in peanut oil at the concentration of $10 \mathrm{mg} / \mathrm{ml}$. It was injected intramuscularly (i.m.) in the rump at 8 to 9 a.m.

The heifers were examined every 2 to $4 \mathrm{hr}$ from $6 \mathrm{a}$.m. to $10 \mathrm{p} . \mathrm{m}$., during the week after progesterone treatments. At all other times the cattle were examined at 8 a.m. and 4 p.m. except on weekends, when they were observed once each day. A heifer was considered to be in oestrus when she allowed another heifer or a sterile male to mount. In most instances behaviour among groups of females made it possible to detect those in oestrus. Nevertheless the sterile males were generally put with the females for short periods. Sterile males were of three

* Present address: Cunningham Laboratory, Mill Rd., St. Lucia, Queensland. 
types: one vasectomized bull; three steers bearing $200 \mathrm{mg}$ testosterone implants each; and one partially castrated bull.

Twenty-four Hereford heifers approximately 15 months old and weighing 500 to $620 \mathrm{lb}$ were put into yards on 4 th December 1961. The ration consisted of approximately equal weights of lucerne hay, oaten hay and oat grain. The average total amount per heifer per day was approximately $10 \mathrm{lb}$ in December 1961 and increased to approximately $13 \mathrm{lb}$ by November 1962. The heifers were fed in groups and were weighed at approximately fortnightly intervals. The ration was varied in order to keep the animals on a steady gain of approximately $0.6 \mathrm{Ib}$ per day.

Commencing on 5th December, the heifers received $30 \mathrm{mg}$ progesterone every 2 days up to and including 15th December. They were then randomly allocated to three groups each of eight heifers. The group treatments were 10 , 20 or $40 \mathrm{mg}$ progesterone per heifer per day for the next 4 days. During the following week the heifers were observed for oestrus. The general procedure was repeated at 7-weekly intervals until 26th November 1962 (date of final injection). However, for the second and subsequent series $40 \mathrm{mg}$ progesterone were given every 2 days; and seven injections were given at intervals of 2 days prior to randomization and commencement of separate group treatments. An interval of 7 weeks was chosen so that the heifers would have experienced one normal oestrous cycle and the majority would be in the mid-luteal phase of the next cycle at the time injections for the next series commenced.

Before the experiment, the possibility of allotting heifers to successive treatments in such a way as to be able to utilize within-heifer variation was considered. It was not implemented because at the time it was uncertain for how long the experiment could be continued. It seems likely, however, that the procedure might have been justified since one heifer consistently came into oestrus approximately $15 \mathrm{hr}$ earlier than the group average and two others were approximately $20 \mathrm{hr}$ later than the group average.

\section{RESULTS}

Differences between heifers in average daily gains were small (the group of twenty-four heifers averaged $0.62 \mathrm{lb}$ per day over the 12 month period), but the range of weights increased from $120 \mathrm{lb}$ (500 to 620) on 4th December 1961 to $260 \mathrm{lb}$ (680 to 940) on 4th December 1962. Ranking tended to be constant: the five heaviest heifers in December 1961 were also the five heaviest a year later, and three of the five lightest in 1961 were among the five lightest in December 1962.

The number of heifers in which ovarian cycles were not completely suppressed is shown in Table 1. The effectiveness of progesterone suppression declined after May and was especially poor in August. At the same time, the number of heifers not showing oestrus during the week following the cessation of progesterone treatment was greatest in the period December to May. These results indicate that equivalent doses of progesterone completely suppressed ovarian function in the period December to May and in some heifers caused a temporary anoestrus. After May, however, progesterone did not suppress 
ovarian function in all heifers, and some entered oestrus within a few days of the cessation of injections.

The periods from the final injection of progesterone to the onset of oestrus are shown in Table 2. The results refer only to heifers in oestrus during the week after treatment, and do not include three heifers that were in heat both during and after treatments.

TABLE 1

OESTRUS AND OVULATION DURING PROGESTERONE TREATMENTS AND DURING THE WEEK AFTER TREATMENT

\begin{tabular}{|c|c|c|c|c|c|c|c|c|c|}
\hline \multirow[t]{2}{*}{$\begin{array}{c}\text { Date of final } \\
\text { injection }\end{array}$} & \multicolumn{4}{|c|}{$\begin{array}{c}\text { No. heifers in oestrus and/or } \\
\text { ovulating during progesterone } \\
\text { treatments* }\end{array}$} & \multicolumn{4}{|c|}{$\begin{array}{c}\text { No. heifers not showing oestrus } \\
\text { during the week following treat- } \\
\text { ment* }\end{array}$} & \multirow{2}{*}{$\begin{array}{l}\text { Total No. } \\
\text { heifers in oes- } \\
\text { trus during the } \\
\text { week following } \\
\text { treatment }\end{array}$} \\
\hline & $10 \mathrm{mg}$ & $20 \mathrm{mg}$ & $40 \mathrm{mg}$ & Total & $10 \mathrm{mg}$ & $20 \mathrm{mg}$ & $40 \mathrm{mg}$ & Total & \\
\hline $\begin{array}{l}\text { 19th Dec. } 1961 \\
\text { 7th Feb. } 1962 \\
\text { 26th March } 1962 \\
\text { 14th May } 1962 \\
\text { 2nd July } 1962 \\
\text { 20th Aug. } 1962 \\
\text { 8th Oct. } 1962 \\
\text { 26th Nov. } 1962\end{array}$ & $\begin{array}{l}0 \\
1 \\
0 \\
0 \\
4 \\
3 \\
2 \\
0\end{array}$ & $\begin{array}{l}0 \\
0 \\
0 \\
0 \\
0 \\
4 \\
2 \\
1\end{array}$ & $\begin{array}{l}1 \\
1 \\
0 \\
0 \\
0 \\
3 \\
0 \\
2\end{array}$ & $\begin{array}{r}1 \\
2 \\
0 \\
0 \\
4 \\
10 \\
4 \\
3\end{array}$ & $\begin{array}{l}1 \\
1 \\
2 \\
1 \\
1 \\
1 \\
1 \\
0\end{array}$ & $\begin{array}{l}1 \\
1 \\
0 \\
1 \\
0 \\
1 \\
0 \\
0\end{array}$ & $\begin{array}{l}0 \\
1 \\
1 \\
4 \\
0 \\
0 \\
0 \\
0\end{array}$ & $\begin{array}{l}2 \\
3 \\
3 \\
6 \\
1 \\
2 \\
0 \\
0\end{array}$ & $\begin{array}{l}21 \\
19 \\
21 \\
18 \\
19 \\
15 \dagger \\
20 \\
22 \dagger\end{array}$ \\
\hline
\end{tabular}

* The groups received $40 \mathrm{mg}$ of progesterone ( $30 \mathrm{mg}$ for the first series) for seven injections at intervals of 2 days prior to daily injections for 4 days of the doses shown.

+ Some heifers showed oestrus both during and after progesterone treatment.

TABle 2

PERIODS FROM FINAL INJECTION OF PROGESTERONE TO ONSET OF OESTRUS (HR)

\begin{tabular}{|c|c|c|c|c|c|c|c|c|c|}
\hline \multirow{3}{*}{$\begin{array}{l}\text { Date of final } \\
\text { injection }\end{array}$} & \multicolumn{9}{|c|}{ Progesterone treatment* } \\
\hline & \multicolumn{3}{|c|}{$10 m g$} & \multicolumn{3}{|c|}{$20 \mathrm{mg}$} & \multicolumn{3}{|c|}{$40 m g$} \\
\hline & $n$ & $\bar{x}(h r)$ & S.E. $\bar{x}$ & $n$ & $\bar{x}(h r)$ & S.E. $\bar{x}$ & $n$ & $\bar{x}(h r)$ & S.E. $\bar{x}$ \\
\hline $\begin{array}{l}\text { 19th Dec. } 1961 \\
\text { 7th Feb. } 1962 \\
\text { 26th March } 1962 \\
\text { 14th May } 1962 \\
\text { 2nd July } 1962 \\
\text { 20th Aug. } 1962 \\
\text { 8th Oct. } 1962 \\
\text { 26th Nov. } 1962\end{array}$ & $\begin{array}{l}7 \\
6 \\
6 \\
7 \\
3 \\
4 \\
6 \\
6 \\
8\end{array}$ & $\begin{array}{l}70 \cdot 9 \\
51 \cdot 3 \\
45 \cdot 3 \\
81 \cdot 7 \\
40 \cdot 0 \\
41 \cdot 5 \\
44 \cdot 3 \\
68 \cdot 0\end{array}$ & $\begin{array}{r}14 \cdot 0 \\
2 \cdot 3 \\
4 \cdot 8 \\
13 \cdot 1 \\
2 \cdot 0 \\
0 \cdot 3 \\
3 \cdot 4 \\
2 \cdot 1\end{array}$ & $\begin{array}{l}7 \\
7 \\
8 \\
7 \\
8 \\
3 \\
6 \\
7\end{array}$ & $\begin{array}{l}62 \cdot 8 \\
67 \cdot 1 \\
86 \cdot 4 \\
86 \cdot 0 \\
50 \cdot 8 \\
73 \cdot 3 \\
44 \cdot 5 \\
96 \cdot 6\end{array}$ & $\begin{array}{r}5 \cdot 5 \\
5 \cdot 2 \\
14 \cdot 1 \\
11 \cdot 1 \\
5 \cdot 5 \\
23 \cdot 7 \\
2 \cdot 9 \\
5 \cdot 3\end{array}$ & $\begin{array}{l}7 \\
6 \\
7 \\
4 \\
8 \\
5 \\
8 \\
6\end{array}$ & $\begin{array}{r}86 \cdot 9 \\
98 \cdot 3 \\
107 \cdot 1 \\
87 \cdot 0 \\
68 \cdot 3 \\
101 \cdot 6 \\
81 \cdot 5 \\
103 \cdot 3\end{array}$ & $\begin{array}{r}9 \cdot 0 \\
4 \cdot 1 \\
6 \cdot 8 \\
8 \cdot 0 \\
7 \cdot 6 \\
13 \cdot 6 \\
7 \cdot 8 \\
5 \cdot 5\end{array}$ \\
\hline
\end{tabular}

$n=$ number of heifers showing oestrus (not including heifers that had shown oestrus during treatment); $\bar{x}=$ mean period to onset of oestrus; s.e. $\bar{x}=$ standard error.

* The groups received $40 \mathrm{mg}$ progesterone ( $30 \mathrm{mg}$ for the first series) for seven injections at intervals of 2 days prior to daily injections for 4 days of the doses shown.

A test for homogeneity of variances (Bartlett's Test: $\chi^{2}{ }_{(23)}=91.94 ; P<$ 0.001 ) was carried out for all twenty-four treatments and it was found that the variances were heterogeneous. Further examination of the data showed that variances in the groups that received $40 \mathrm{mg}$ progesterone were not heterogeneous $\left(x^{2}(7)=7.28 ; 0.3<P<0.5\right)$. The groups that received $20 \mathrm{mg}$ progesterone 
had variances similar to those of the $40 \mathrm{mg}$ group except for series 3,4 and 6 , and in the groups that received $10 \mathrm{mg}$ progesterone there was considerable heterogeneity of variances during the first six series. The overall pattern of variances was that all treatments gave homogeneous results in the final two series, but there was a relationship between dose of progesterone and withingroup variance in the first six series; the greatest variation was associated with the smallest dose.

An overall analysis of variance was not possible because of the heterogeneity of variances. Also, at certain times and after certain doses the number of heifers showing oestrus was less than half the total in the group.

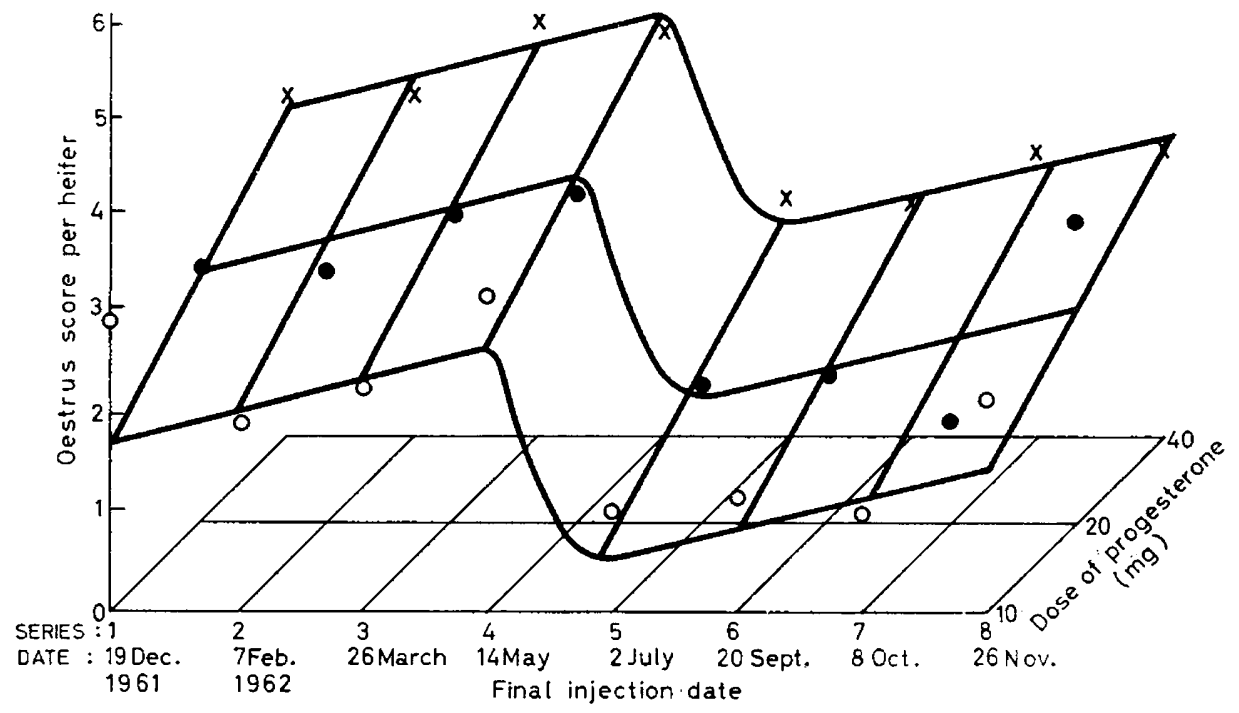

TEXT-FIG. 1. Graphical representation of the effect of three dosage levels of progesterone on the 'oestrus score' per heifer at eight times throughout the year. The heifers received $40 \mathrm{mg}$ progesterone every 2 days for seven injections prior to daily injections for 4 days of the following doses: $0,10 \mathrm{mg} ; 0,20 \mathrm{mg} ; \times, 40 \mathrm{mg}$.

A method of analysis was decided after perusal of the results in Tables 1 and 2. The period from the final injection of progesterone to onset of oestrus seemed to be greatest in March and May and least in July and October. The August results were influenced by a severe snow storm which commenced on the evening of 21 st August and continued for $24 \mathrm{hr}$, and, in addition, nearly half the heifers experienced oestrus during the progesterone treatment. It was decided to test whether a seasonal change in the effects of progesterone had occurred by allotting a score to each heifer for each series on the following basis:

0 Oestrus and/or ovulation during treatments.

1 Oestrus less than $48 \mathrm{hr}$ after final injection of progesterone.

2 Oestrus 49 to $72 \mathrm{hr}$ after final injection of progesterone.

3 Oestrus 73 to $96 \mathrm{hr}$ after final injection of progesterone.

4 Oestrus 97 to $120 \mathrm{hr}$ after final injection of progesterone.

5 Oestrus $>120 \mathrm{hr}$ after final injection of progesterone, or no oestrus in the week after progesterone treatment. 
The group total scores are plotted in Text-fig. I and an analysis of variance was also conducted. The curves were fitted on the basis of the results of the analysis. The results show that the dose of progesterone over the final 4 days of treatment influenced the position of the seasonal response curves; the shape of the curves was similar for all doses. There was a gradual increase in the suppressive action of progesterone until May, but between May and July its effect was suddenly reduced. This was followed by a steady increase in suppressive action.

\section{DISCUSSION}

Heifers maintained in yards on a ration that gave an average of $0.62 \mathrm{lb} /$ day gain in weight, showed seasonal changes in their response to progesterone. Progesterone suppressed ovarian cycles satisfactorily during the period December to May, but comparable dosage levels were less effective in the period July to October. Oestrus generally occurred at a shorter time after the final injection of progesterone in the period July to October. Thus the response to comparable doses of progesterone varied during the year, and the general effect of, say, $10 \mathrm{mg}$ of progesterone in May was indistinguishable from that of $20 \mathrm{mg}$ in March or a dose somewhat greater than $40 \mathrm{mg}$ in July. There was also a characteristic dose-response pattern throughout the year in that the period from the final injection of progesterone to the onset of oestrus was related to the dose of progesterone.

It therefore seems reasonable to suggest that the differences between doses of progesterone at the one time and between the same dose at different times have a common basis. This would most likely be true if the suppressive effect of progesterone was centred on a pathway that was influenced by both hormones and external stimuli. The control of seasonal reproductive rhythms is thought to be situated in the hypothalamus (Everett, 1961), hence it is possible that progesterone exerts its suppressive action on the ovary via the hypothalamus.

A similar seasonality in effect of progesterone has been reported in ewes (Lamond, 1964b). A sudden change in the effect of progesterone occurred in ewes in June and July but was opposite in direction to that described here for cattle. However, this may be expected since anoestrus normally occurs in spring and summer in ewes, whereas anoestrus in cattle is generally confined to the winter months and is usually seen only in heifers. Lamond (1964b) indicated how the change in effect of progesterone may be related to the onset of anoestrus.

The snow storm which occurred at a critical time in series 6 was quite exceptional for the district. It is possible that the stress came too late to stop all the heifers in the $10 \mathrm{mg}$ group and two heifers in the $20 \mathrm{mg}$ group from coming into oestrus. The remaining heifers entered oestrus about $24 \mathrm{hr}$ later than expected on the basis of the July and October results. This raises the question of whether the sudden climatic change may have postponed follicle maturation.

\section{ACKNOWLEDGMENTS}

The assistance of D. R. Lang, I. Bennett and J. Jones is gratefully acknowledged. 


\section{REFERENCES}

Christian, R. E. \& Casida, L. E. (1948) The effects of progesterone in altering the oestrous cycle of the cow. F. Anim. Sci. 7, 540 .

EVERETT, J. W. (1961) The mammalian female reproductive cycle and its controlling mechanism. Sex and Internal Secretions, vol. 1. Ed. W. C. Young. Bailliere, Tindall \& Cox, London.

LAMOND, D. R. (1962) Suppression of ovarian cycles in sheep using progesterone. Artificial Breeding of Sheep in Australia. Ed. E. M. Roberts. University of N.S.W., Sydney.

LAMOND, D. R. (1964a) Hormonal synchronization of ovulation in beef heifers and fertility after artificial insemination. Aust. F. agric. Res. 15, 461.

LAMOND, D. R. (1964b) Seasonal changes in the occurrence of oestrus following progesterone suppression of ovarian function in the Merino ewe. J. Reprod. Fertil. 8, 101.

Zimbelman, R. G. (1961) The control of oestrus and ovulation in heifers by orally administered 6-methyl-17-acetoxy-progesterone. J. Dairy Sci. 44, 1195. 